\title{
煩脂肪体有茎移植によるロ蓋欠損の閉鎖手術
}

\author{
藤村長久 久名 倉 英明・榎本昭二

\section{Closure of palatal defects with pedicled graft of buccal fat pad}

\author{
Nagahisa Fujımura - Hideaki Nagura $\cdot$ Shoji Enomoto
}

\begin{abstract}
Pedicled graft of buccal fat pad with lyophilized porcine dermis was used for the closure of 6 cases of palatal defects due to surgery of maxillary tumors. In four cases the oroantral and/or oronasal communications were closed, and in two cases exposed bone and muscles were covered. Three of 6 cases were of squamous cell carcinoma originating from gingiva and three were of either ameloblastoma or pleomorphic adenoma.
\end{abstract}

Results of 6 cases to which this method was applied are as follows.

1. This method could be applied to large palatal defects; in our cases the maximum defect size was $60 \times 50 \times 30 \mathrm{~mm}$.

2. Epithelialization generally occurred in about two weeks in conjunction with dissolution of the lyophilized porcine dermis.

3. The epithelialized tissue possessed similar characteritics to normal palatal mucosa.

4. Epithelialization was not affected by either radiotherapy or chemotherapy.

Key words: buccal fat pad (頓脂肪体), pedicled graft（有茎移植), palatal defect（口蓋欠損）

緒言

上顎尰堭の切除手術に際し，口蓋欠損をきたし，口腔 と上靧洞，あるいは口腔と鼻腔とが交通することが多 い. 従来，このような欠損，穿孔を閉鎖する方法とし

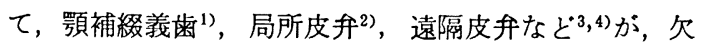
損の部位，大きさ，疾患の性質に応じて適用されてき た. 第 1 の䫇補緅義歯による閉鎖法は主に上頂の悪性腫 瘍に対して適用され，特に三者併用療法においては，腫 瘍壊死組織の搔爬，および十分な視野に基づく予後観察 が可能であるといら利点を有しているが，欠損の位固， 大きさによっては顎補綴義歯の安定性が低下しやすいと い5欠点をもっている. 第 2 の局所皮弁の方法として は，一般に煩粘膜弁，口蓋粘膜弁による閉鎖が行われて

東京医科隧科大学檤学部第 2 口腔外科学教室 （主任：榎本昭二教授）

The Second Department of Oral and Maxillofacial Surgery, Faculty of Dentistry, Tokyo Medical and Dental University (Chief: Prof. Shoji Enomoto) 受付日：昭和63年12月 26 日
いるが，弁の可動範囲に制限があるため大きい欠損には 適用乙得ない。一方， 口蓋島状粘膜弁 ${ }^{5)}$ による閉鎖法は より可動性に優れているが，やはり閉鎖すべき欠損の大 きさには限界があり，また支配血管の大口蓋動脈の保存 が必要であることから，これを切除範囲に含む症例には 適用し得ない，第 3 の遠隔皮并の方法として最も一般的 なのは舌弁 ${ }^{6)}$ であるが，欠損の大きさに限界があり，ま た患者に与える負担が大きい。前額皮弁 ${ }^{3)}, \mathrm{DP}$ 皮型 ${ }^{4)}$ に よる閉鎖は欠損の位置，大ささに左右されないか，その 性状は口蓋粘膜と全く異なるため，義歯の安定性に乏し

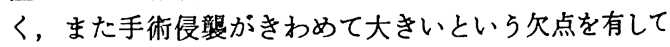
いる.

これに対し Egyedi は7)， 口蓋欠損に基つくくロ腔上靧 洞交通，口腔奥腔交通を頓脂肪体有茎移植により閉鎖 し，その有用性を報告した。さらに Tideman ら゙は， 上顎のみならず下顎, 頓粘膜の再建にこの有茥移植を適 用し，有効な成績を拈さめた。われわれもこれまでに， 上顎良性，悪性腫瘍の切除手術により口蓋欠損をきたし た症例に対し，煩脂肪体有茎移植と凍結乾燥豚真皮を用 いて，一次的に欠損を閉鎖することを試み，良好な結果 が得られたので，報告する． 


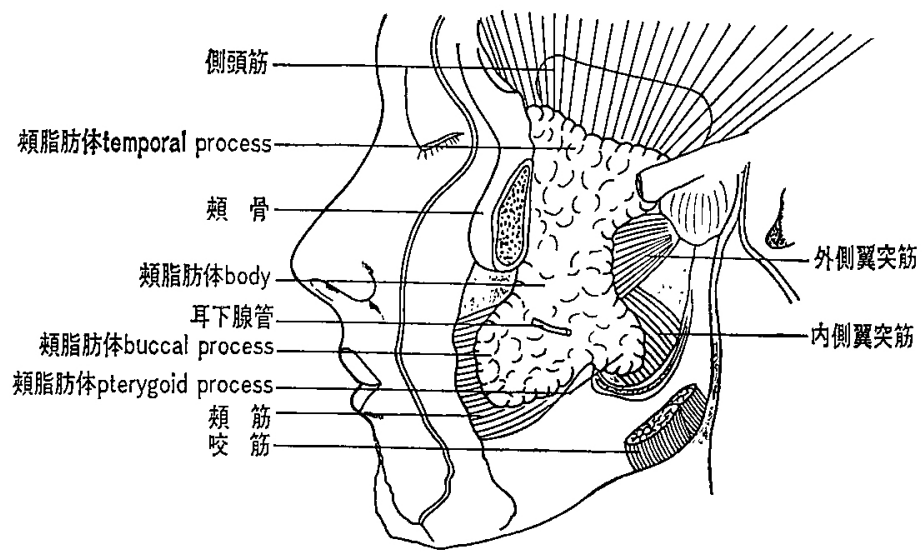

図 1 煩脂肪体の解剖 (pterygopalatine process は省略)

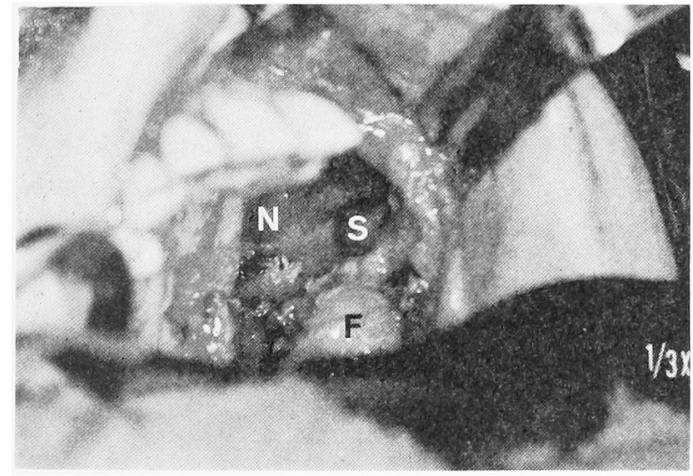

写真 1 症例 1

上颚部分切除後, 賽脂助体が自然に露出した状態 （F：類脂肪体， $\mathrm{N} ：$ 鼻監， $\mathrm{S} ：$ 上顎洞）

\section{解剖，手技および治瘾経過}

Gaughran ${ }^{9}$ 飞上れば，頼脂肪体は中心部の体部 body と4つの突起 extention or process から構成されてい る(図 2)，体部は後方上顥骨膜 と頌筋後上方部の間に 存在し，これより前方へ buccal process, 内方へ pterygopalatine process, 上方へ temporal process, 後下方 へ pterygoid process が伸びている. buccal process は 頓筋と咬筇 の間飞存在し，咬能前縁部まで達する。 pterygopalatine process は翼口蓋窩に存在し，この部を 通り神経血管束を包みながら，正円孔より頭蓋内に達し ている。 temporal process は最も発達が良く，側頭筋 前方部と頼骨後内面の間汇存在している. pterygoid process は後下方に存在するもので，外側，内側翼突筋 と接している.

したがって，口蓋欠損部の閉鎖に対しては，主に頓脂 肪体の体部および buccal process が使われることにな

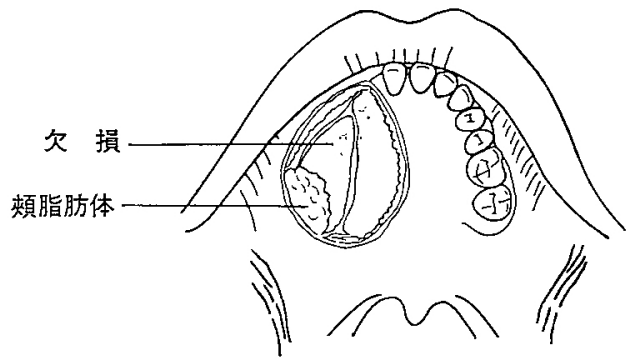

図 2 頼脂肪体へのアプローチ（I） 上顎部分切除術においては，頓脂肪体が 自然簬出してくる

る. 上頱切除手術に際し, 日歯相当部歯肉頓移行部より 上方に切開線が設定されれば，切除辺縁に自然に䫅脂肪 体が露出してくる（写真1，図2）ので，これを周囲組 織より鈍的に虽離し，欠損部汇誘導する。，一方，切除が

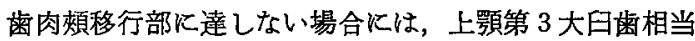
部括よび筇乫起前縁部に相当する煩粘膜に切開を入れる ことにより頓脂肪体を露出させる．次にこの切開部と欠 損辺縁の問の粘膜下を剥離し，この下を通して頼脂肪体 を欠損部に誘遒する(图 3)，誘導した頼脂肪体を欠損 部辺縁の周囲粘膜と縫合した（写真 2) 後, さらにこの 上を涷結乾燥豚真皮にて被覆し，これを周围粘膜に縫合 する (写直 3)，最後に凍結乾燥豚真皮の 固定，接着抽 よび創の保護を目的として，抗生物質含有軟高ガーゼを 固き，床副子を装着する（写直 4 ）。

術後約 1 週で床副子，ガーゼを除去すると，凍結乾嬠 豚真皮は一部融解し，黄色の脂肪組織は僅かに散見され るたけで，移植部全体は赤褐色の肉芽組織に覆われてい た. 以降凍結乾燥原真皮の融解の進行とともに, 頼脂肪 体の表面の上皮化が進行し，移植部は一般に 2 週で上皮 様組織となり，周用健常粘膜と变わらない状態となっ 


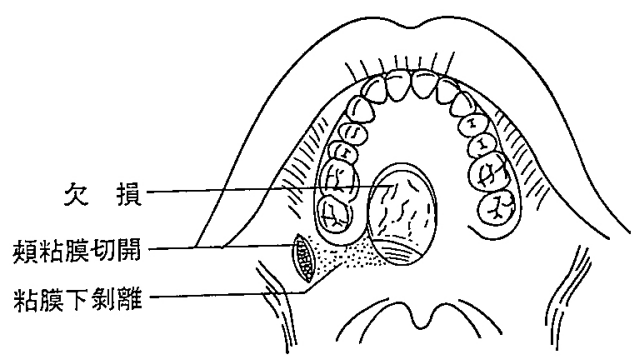

図 3 頓脂肪体へのアプローチ（II）

口蓋のみの久損では，煩粘膜切開により露出させ た煩䀝肪体を粘膜下を通して欠損部に誘尊する

た。

\section{対象症例}

症例は1986年11月より1988年 4 月までの約 1 年半の間 に，当科にて上䫇尰湯の手術を施行した後，一期的に本 法を適用した 6 症例で, 性別, 年齢, 疾患名は図 4 K要 約した。手術により生じた口腔一上䫇洞交通ないし口腔 鼻腔交通の閉鎖を行った症例は 4 例で，らち1例は上頡 エナメル上皮腫, 他の 3 例は崡肉由来の上買扁平上皮 癌であった．上顎癌 3 例のうち大きさが最小のものは $18 \times 13 \mathrm{~mm}$, 最大のものは $24 \times 6 \mathrm{~mm}$ であった。 また 1 例は術前に放射線治療怙よび局所動注化学療法が施行 された，一方，手術により生じた骨露出面，筋露出面を 被得した症例は 2 例で，いずれる口䔔多形性腺腫であっ た。

\section{結果および症例}

頼脂肪体有茎移植を施行した 6 症例の結果に関しては 图4 K要約した。

手術により生じた上顎口蓋部，畨槽部の欠損の大きさ は最小 $15 \times 15 \mathrm{~mm}$ で, 最大 $60 \times 50 \times 30 \mathrm{~mm}$ であった。 移植部の感染, 壊死は全例に認めなかった，1 例に移植 部の一部脱落， 1 例に帽針頭大の欠損を認めた，煩脂肪 体を採取することによる煩部の陷凹なと，術後の顔面変 形は全例に認めなかった。

以下，代麦的症例を報告する。

症例1 (No. 1)

患 者: 60盛 男性.

現 症： 56 部口蓋側肉に $18 \times 13 \mathrm{~mm}$ の潰瘍を認 める (写真 5 ).

$\mathbf{X}$ 線所見， CT 所見：上顎骨，上顎崡槽骨扎上び上顎 洞粘膜に变化を認めない。

診 断：上靧肁平上皮癌, $\mathrm{T}_{1} \mathrm{~N}_{0} \mathrm{M}_{0}$.

処置および経過：前方は12 より後方は左上䫇結節ま

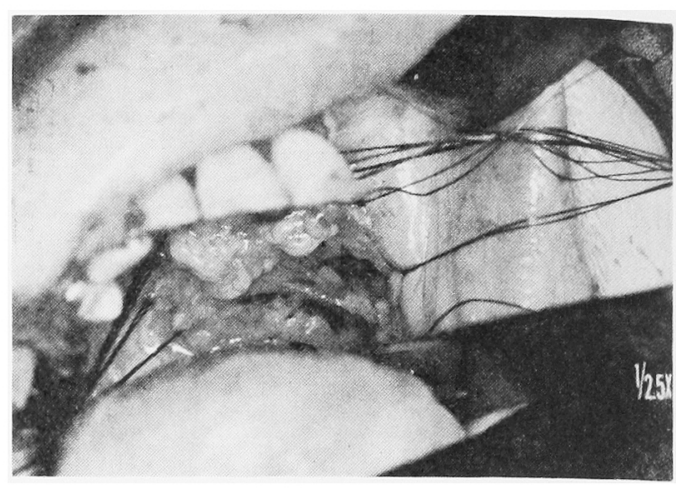

写真 2 症例 1

頓脂肪体の欠損部への繾合

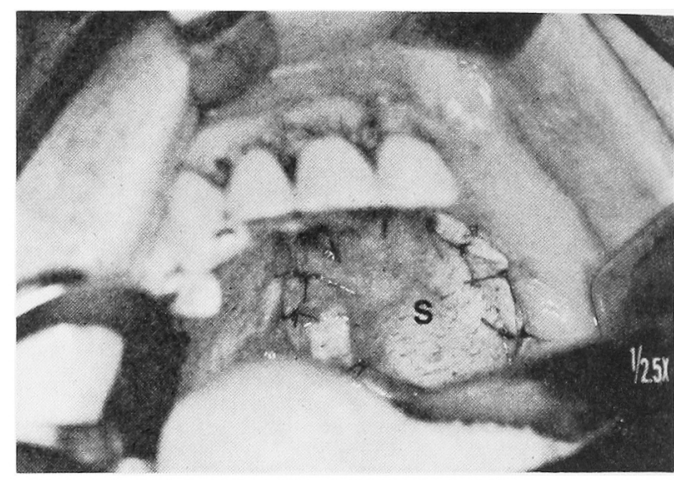

写真 3 症例 1

凍結乾燥豚真皮 $(\mathrm{S})$ の䌍合

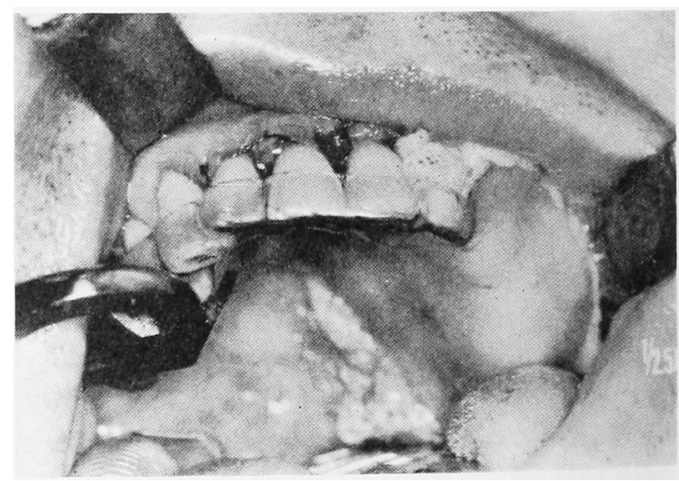

写真 4 症例 1

軟高ガーゼ，床副子の装着

で，内側は艒中隔を残して口蓋正中まで，外側は上靧洞 前壁，側壁を含んで上顎部分切除術を施行した．切除に より生じた $60 \times 50 \times 30 \mathrm{~mm}$ の口蓋欠損のため，口腔と 上靧洞および舅腔とが交通した（写直1）。これに対し 頓脂肪体を移植して交通部を閉鎖した（写真 2). 術後 


\begin{tabular}{|c|c|c|c|c|c|c|c|}
\hline \multicolumn{2}{|c|}{ 恘: 例 } & 1.M.Y. & 2.K.T. & 3.T.K. & 4.F.S. & 5.T.S. & 6.H.F. \\
\hline \multicolumn{2}{|c|}{ 性 } & $\mathrm{M}$ & $\mathrm{M}$ & $\mathrm{F}$ & $\mathrm{F}$ & M & $\mathrm{F}$ \\
\hline \multicolumn{2}{|c|}{ 年䏩（歳） } & 60 & 41 & 61 & 69 & 48 & 49 \\
\hline \multirow[b]{2}{*}{ 㰡 } & 診 断 & 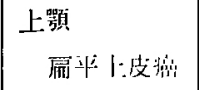 & $\begin{array}{l}\text { 上鄂! } \\
\text { エナメル_l:皮胢 }\end{array}$ & 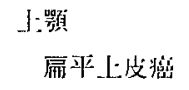 & 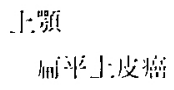 & $\begin{array}{l}\text { 山罢: } \\
\text { 多形性腺腄 }\end{array}$ & $\begin{array}{l}\text { 口琶 } \\
\text { 多形性腺晅 }\end{array}$ \\
\hline & 位消: & 56 部四箩 & 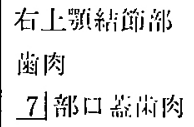 & $\begin{array}{l}7 \text { 湖および後 } \\
\text { J雨闪 }\end{array}$ & 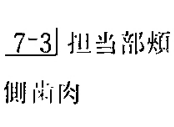 & 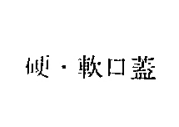 & 䎶口望 \\
\hline \multirow{2}{*}{ 㤁 } & $\begin{array}{l}\text { 大き光 } \\
(\mathrm{mm})\end{array}$ & $18 \times 13$ & $13 \times 12$ & $21 \times 11$ & $24 \times 6$ & $34 \times 28$ & $28 \times 28$ \\
\hline & TNM & $\mathrm{T}_{1} \mathrm{~N}_{0} \mathrm{M}_{0}$ & - & $\mathrm{T}_{2} \mathrm{NaM}_{0}$ & $\mathrm{~T}_{2} \mathrm{~N}_{0} \mathrm{M}_{0}$ & 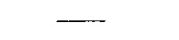 & - \\
\hline fi! & $\begin{array}{l}\text { 位漰 } \\
\text { および } \\
\text { 大きき } \\
(\mathrm{mm})\end{array}$ & (iv) & (3) & (iv) & & (iin) & (iis) \\
\hline ti! & 結 果 & $\begin{array}{l}\text { 帽針状大の久損 } \\
\text { 義娄装福 }\end{array}$ & 是 & $\begin{array}{l}\text { 一部脱落 } \\
7 \times 4 \mathrm{~mm} \sigma \text { 人弶 }\end{array}$ & 是 & 息 & 良 \\
\hline \multicolumn{2}{|c|}{ その他 } & & & & $\begin{array}{l}\text { 術前版射線 } \\
\text { 治療 } \\
\text { 術前化学療法 }\end{array}$ & 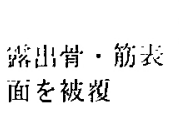 & $\begin{array}{l}\text { 歌出骨・筋表 } \\
\text { 面を被襀 }\end{array}$ \\
\hline
\end{tabular}

図 4 頼脂肪体有茎移植を適用した 6 症例の要約

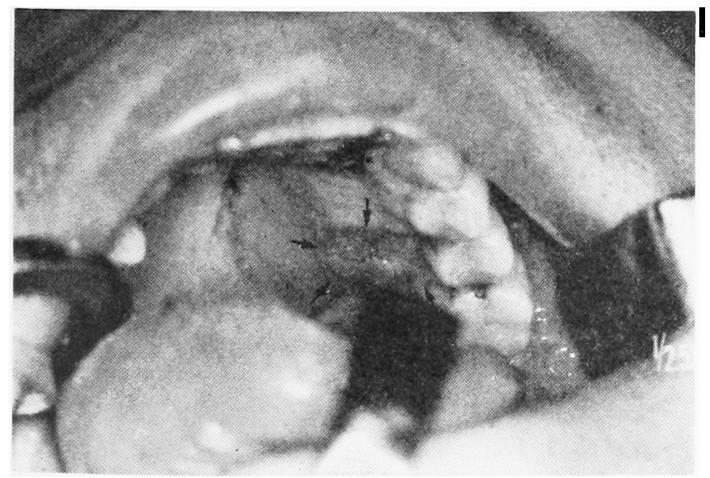

写真 5 症例 1

街前口腔内所見（知印：病変部）

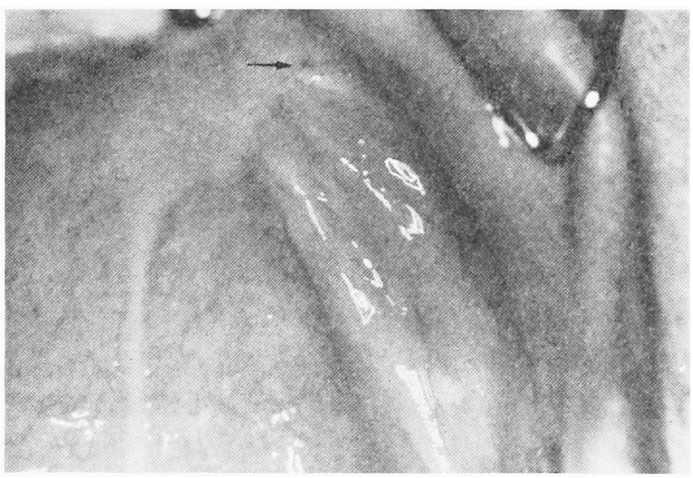

写真 6 正例 1

術後 1 年の口腔内所見. 移植前方部に 帽針頭大の欠損（失印）を認める 


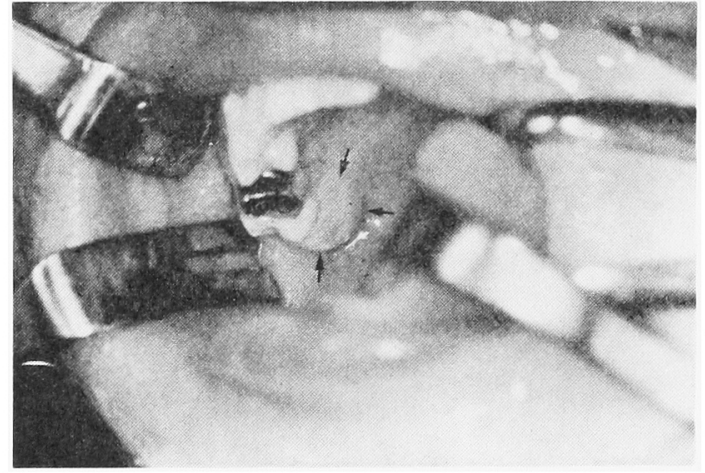

写真 7 症例 2

術前口室内所見（矢印：病变部）

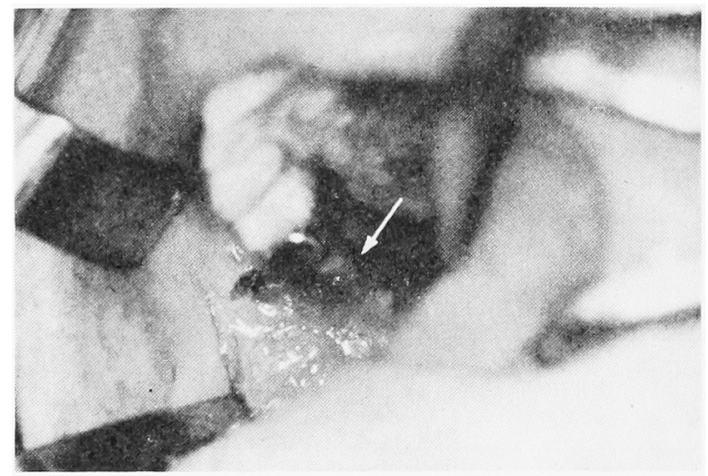

写真 8 症例 2

上顯部分切除後の口腔一上頻洞交通（矢印）

2 週で移植部表面に上皮様組織が再生したが，移植部前 方端に小さな欠損を認めた。術後 1 年後にはこの欠損は 帽針頭大となり (写直 6 ), さらに約 1 年半後の現在,

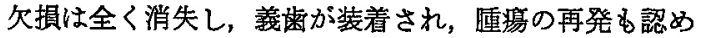
ない。

\section{症例 2 (No. 2)}

患 者: 41 藏 男性.

現 症：右上顎結節部粘膜 おょび 7 部口蓋側透肉 飞, $13 \times 12 \mathrm{~mm}$ の境界不明膫な隀脹を認める (写真 7 ). 診 断：上顕エナメル上皮連.

処置および経過：前方は 6 ，後方は右上罘結節まで, 腫焬辺縁より $5 \mathrm{~mm}$ 外側に切開線を設定し主に歯槽部 の上顠部分切除術を施行した. $18 \times 17 \mathrm{~mm}$ の口蓋欠損 が生じ，口腔と上顎洞とが交通した（写真 8 ）ため，頓 脂肪体を移植して閉鎖した（写直 9 ). 術後 2 週で，移 植部はほぼ上皮様組織で覆われ（写真10), 術後約 1 年 の現在，移值部は周困粘膜と変わらない状態で，腫㻛の 再発子みられない。

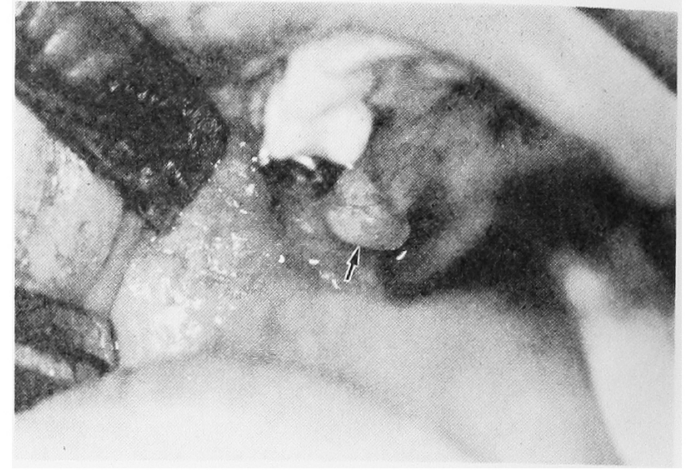

写真 9 症例 2

久損部への頓脂助体（矢印）の移植

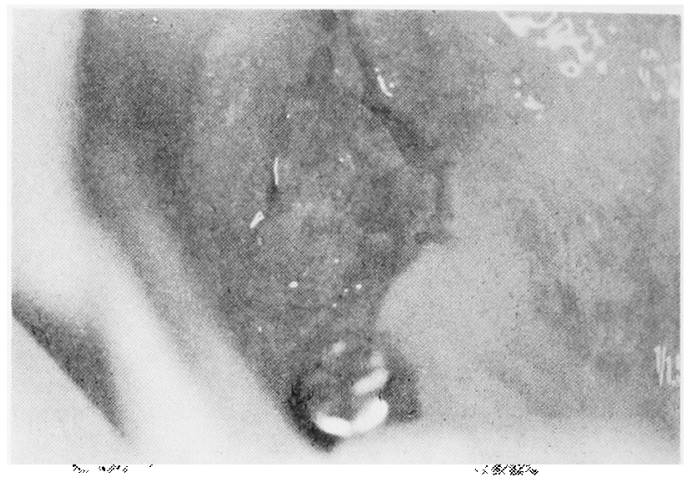

写真 10 症例 2

得後 2 週の煩脂肪体移植部の状態

（ミラー使用により撮影）

症例 3 (No. 4)

患 者: 69歳 女性.

現 症: $\underline{7-3}$ 相当部頓側歯肉に $24 \times 6 \mathrm{~mm}$ の潰場を 認める (写真11).

$\mathbf{X}$ 線所見， CT 所見：X線所見では特記事項はない.

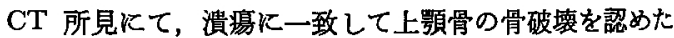
が，上頻洞粘膜には変化を認めない。

診 断：上頡扁平上皮癌, $\mathrm{T}_{2} \mathrm{~N}_{0} \mathrm{M}_{0}$

処置および経過：放射線治寮 $\left({ }^{80} \mathrm{Co}\right.$ 外照射 $\left.232.5 \mathrm{~Gy}\right)$ 拈よび顎動脈局所動注化学潦法 (5 Fu $\Sigma 3,750 \mathrm{mg}$ ) を施 行した後，前方は I相当部より後方は右上䫏結節まで， 外側は眼窩下孔下方の上額洞前壁，側壁を含めて上影 部分切除術施行した．生した上靧欠損，口腔一上䫑洞 交通を閉鎖するため，煩脂肪体を移植した。術後8日 目, 凍結乾燥㕄真皮は一部融解乙, 脂肪組織と肉芽組織 とが混在している状態であった（写真12）．上皮様組織 の再生はやや遥延したが，感染，壊死はみられず，術後 約 3 週で上皮再生が認められた. 術後 6 か月後の現在, 移植部の粘膜は周囲粘膜と変わらない状態となって拉 


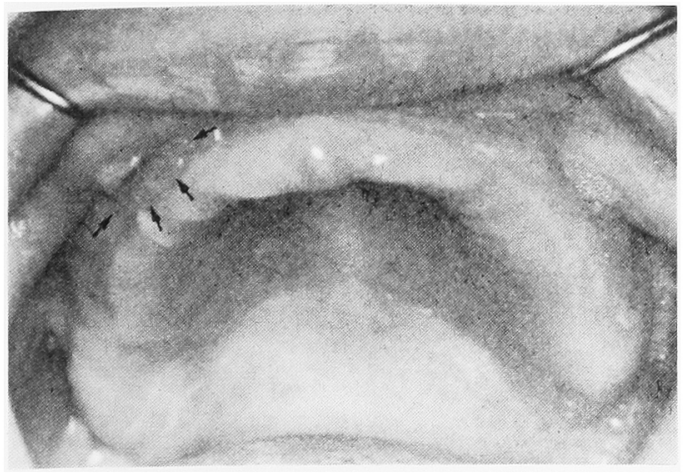

写真 11 症例 3

㭪前口腔内所見（矢印：病变部）

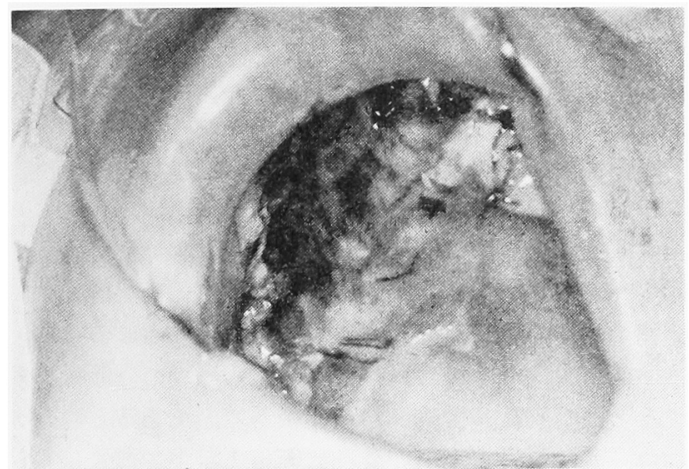

写真 12 症例 3

術後 8 日の煩脂肪体移植部の状態

り，義歯か゚装着されている，腫瘍の再発はみられない (写真13)

症例 4 (No. 5)

患 者: 48歳 男性.

現 症：硬口蓋より軟口蓋にわたって，34×28 mm, 弾性硬，半球状で，周囲との境界が比較的明瞭な腫瘤を 認める(写真14).

診 断：口蓋多形性腺腫.

処置および経過：切開線を，腫瘍より $5 \mathrm{~mm}$ 外側に 設定し，口蓋粘膜を含めて，畽湯を切除，摘出した。切 除により $30 \times 28 \mathrm{~mm}$ の口蓋部の骨および軟口蓋の筋が 露出した， $\underline{8}$ 相当部頓粘膜を切開し, 煩脂肪体を剝離, 抽出し，さらにこの切開部と口蓋欠損部の間の粘膜下を 剝離し，これを通して煩脂肪体を欠損部に誘導，移植し た。術後 1 週で肉芽組織の增殖が良好に翟められ（写真 14），2週で注上皮様組織の再生がみられた（写真15）. 䄪11か月後の現在, 移植部の上皮は周囲粘膜 と変わら ず, 腫垤の再発も認めない.

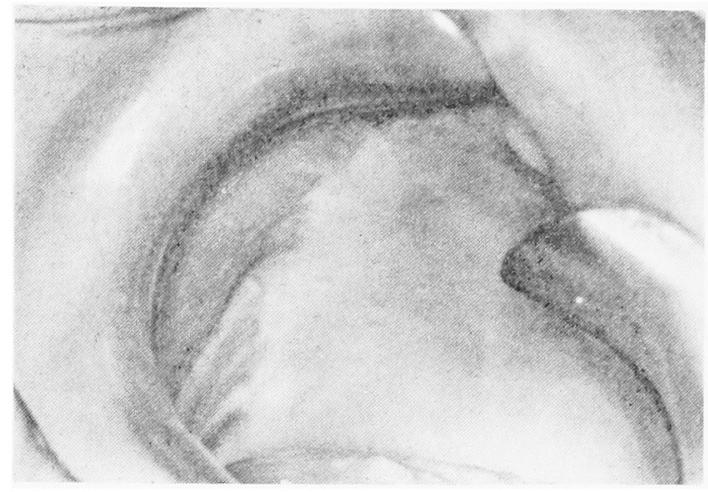

写真 13 症例 3

術後 6 か月の口腔内所見

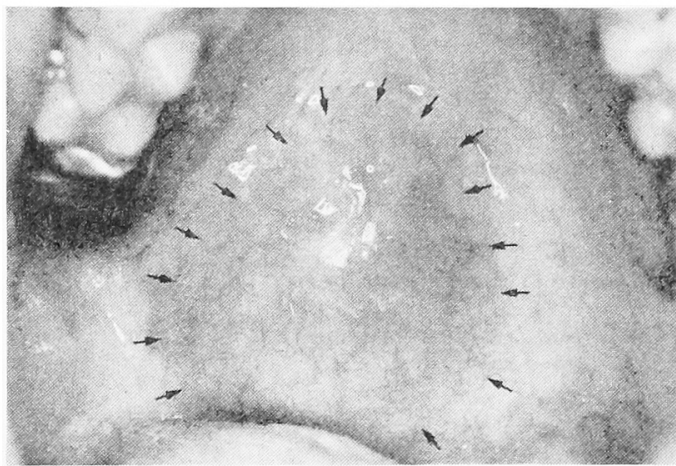

写真 14 症例 4

術前口腔内所見（失印：病变部）

考察

賽脂肪体は顎口腔領域の手術に沶いて，比較的頻繁に 触れる機会の多いるのであるが，その解剖に関してはあ まり明らかになって扣らず，1957年 Gaughranの記述 ${ }^{8)}$ 以外みるべきものがない，彼によれば，煩脂肪体の中心 は，先に述べたごとく，内側は上買骨後方部および頓筋 に接し，外側は下顎枝および咬筋に接する部に存在する （图1）ので，これを適用する欠損の位圆としては，上 顎後方歯槽部を含さのが手技上最も有利である。しか し，本症例 No. 5，6 のごとく，歯槽部を含まない口蓋 欠損の場合でも，頼粘膜切開と欠損部の間に作製した粘 膜下トンネルに煩脂肪体を通すことにより適用すること が可能である．Egyedi は7) 頓脂肪体の体積を約 $10 \mathrm{~cm}^{3}$ と推測し，直径 $4 \mathrm{~cm}$ までの口蓋欠損を被覆できると報 告しているが，Tideman $5^{8)}$ は $3 \times 5 \mathrm{~cm}$ の欠損に利用 し成功を等さめており，われわれも症例 1 のごとく，口蓋 半分に近い $60 \times 50 \times 30 \mathrm{~mm}$ の口腔一上靧洞，口腔一鼻 


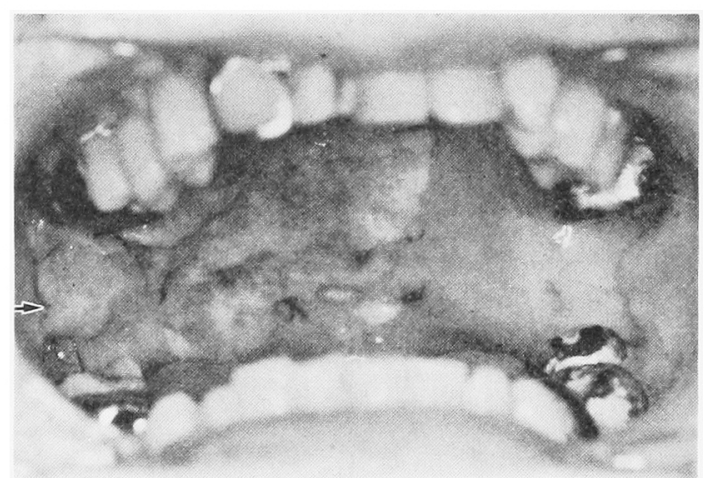

写真 15 症例 4

行後 1 週の煩脂肪体移植部の状態

腔交通を閉鎖し満足のいく結果を得た。本症例の経験か ら，内側へは口蓋正中近くまで，前方へは上顎切雪部ま で煩脂肪体を誘導することが可能であると考えている.

本症例 6 例の5ち，3 例は㧘肉由来の扁平上皮癌であ

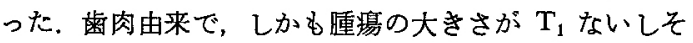
れに近く，洞粘膜に明らかな病変が誌められない症例に 対しては，相治的切除手術の後一期的に欠損部の閉鎖を はかることは，口昷機能の回復をより早く達成すること ができ，妥当な方法と思われる，またその場合，腫瘍の 大きさが径 $20 \mathrm{~mm}$, safety margin を 15〜20 mm とし て，50〜 60 mm の久損が生ずることになるが，先に述 べたごとく，この大きさの欠損の閉鎖は技術的にも可能 である.

本症例中 2 例は良性腫湟切除, 摘出後, 露出した口蓋 部骨面と筋組織を頓脂肪体で被覆したものであった。一 般にこのよ5な場合, 露出した切除創の上に自然に上皮 化が進むことを期待することが多いが，それに比較して 本法を適用した場合，上皮化が早く，また露出した筋組 䅧の洀浪治癒が少ないため，術後の開口障害および軟口 蓋の可動性の制限がきわめて僅かであった。

煩脂肪体の血管支配に関して，Tideman ら を使った外頸動脈血管造影の結果では, 䪽動脈の枝の頓 動脈, 深側頭動脈，また浅側頭動脈の枝の顔面横動脈お よび顔面動脈の枝が動脈支配していることが確かめられ ている.したがって，上靧切除に際して檥牲となりやす い血管からの血流を受けていないため，適用範囲はかな り広いと考党られる。

欠損部に誘導された煩脂肪体に対し，本法を最初に報 告した Egyedi は7)，その表面に中間增植皮を行ったが， Tideman $5^{8)}, \mathrm{Hai}^{10)}$ は，移植した頓脂肪体を口腔内に 露出したままにし，その表面が上皮化することを報告し ている。われわれは全症例とも，煩脂肪体の表面を凍結 乾燥豚真皮で被覆し，その治瘾経過を観察したが，上皮 様組織の再生は速やかで，感染る認められず，をた再生

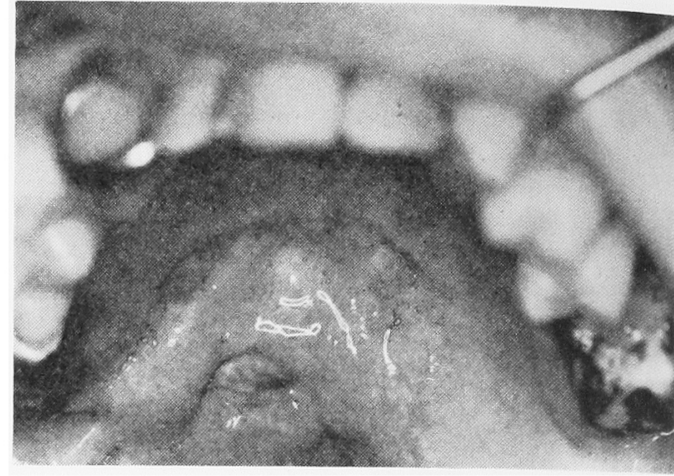

写真 16 症例 4

静後 2 週の䫅脂肪体移植部の状態

した上皮は滑らかで，健常口腔粘膜と変わらないことを 確認した．したがって，移植した頓脂肪体の上に凍結乾 蜗豚真皮を被覆することにより，感染防止，肉茅組織の 形成促進拉よび上皮化の促進，症痕組織の抑制などの効 果11があったものと考えられた。

本法に伴う合併症としては， 1 例に術後の帽針頭大の 瘦孔，1例に頓脂肪体の部分的脱落を認めた，前者は本 症例中最大の欠損に適用したもので, 移植体茥から最す 遠い前齿槽部に瘦孔が残遗したが，瘦孔の位置を考虑 すると煩脂肪体辺緑にかかる緊張が原因であると考えら れた。しかし，本症例の瘦孔は術後 1 年半で消失し全く 問題を生じかった，後者は，術後 1 週目て，抗生物質 含有軟育ガーゼを除去した時点で煩脂肪体の一部脱落が 発見されたもので，ガーぜの量が過多であったこと，頓 脂肪体の抽出の際に周困組織の剩離が十分でなかったこ となどより，移植した煩脂肪体に過度の毉張が加わった ことが原因と考えられた。したがって，両症例とも血流 障害による頓脂肪体の壇死とは考えられなかった，術 前, 術後の放射線治療, 局所動注による化学療法を施行 した後，上顎部分切除術を行った 1 症例に本法を適用し たが，㚘脂肪体の感染，㳖死などは認めなかった，上皮 化が他の症例に比べてやや遷延した印象は受けたが，年 路が69歳と本症例中最高路であることを併せて考虑する と，本法は放射線治療，化学療法にあまり影響を受けな いものと考えられた。

以上より，本法の 長所として，1. 比較的広範囲の口 蓋欠損に適用しうる，2．手技的に容易で手術侵㫛が少 ない，3．上皮化は速やかて，上皮化後，硬度，感触か 口蓋粘膜に近い性状となり，義歯の安定性に優れてい る，4. 放射線治療，化学療法の影響を受けない，など の事項が揭げられ，上顎後方歯槽部を含さか，あるいは それに近接した部に生じた口腔一上顎洞交通，口堅一梨 腔交通ないし口蓋欠損を閉鎖する5えで有用な方法と考 えられた。 


\section{結}

\section{語}

頓脂肪体有茎移植と凍結乾燥豚真皮を用いて，上顎腫 湯 6 症例の腫湯切除後に生じた口腔一上䫇洞交通，口腔 一鼻腔交通および口蓋欠損を閉鎖，被覆したところ良好 な結果が得られたので, 頓脂肪体の解剖, 本法の手技打 よび特徵を述べ，自験例を紹介するとともに考察を加兄 て，その有用性を報告した。

本論文の要旨は, 第42回日本口腔科学会総会 (1988年 6 月16日，於札幌）で発表した。

\section{引用 文 献}

1) Wright, S.M., Pullen-Warner, E.A., et al.: Design for maximal retention of obtulator prosthesis for hemimaxillectomy patients. J Prosthet Dent 47: 88-91 1982.

2) Awang, M.N.: Closure of oroantral fistula. Int J Oral Mxillofac Surg 17: 110-115 1988.

3) Edgerton, M.T. and Devito, R.V.: Reconstruction of palatal defects resulting from treatment of carcinoma of palate, antrum or gingiva. Plast Reconstr Surg 28: 306-319
1961.

4) Park, J.S., Sako, K., et al.: Reconstructive experience with medially based deltopectral flap. Am J Surg 128: 548-552 1974.

5) James, R.B.: Surgical closure of large oroantral fistula using a palatal island flap. J Oral Surg 38: 591-595 1980.

6) Posnick, J.C. and Getz S.B.: Surgical closure of end-stage palatal fistulas using anteriorlybased dorsal tongue flap. J Oral Maxillofac Surg 45: 907-912 1987.

7) Egyedi, P.: Utilization of the buccal fat pad for closure of oro-antral and/or oro-nasal communications. J max-fac Surg 5: 241-244 1977.

8) Tideman, H., Bosanquet, A. et al.: Use of the buccal fat pad as a pedicled graft. J Oral Maxillofac Surg 44: 435-440 1986.

9) Gaughran, G.R.L.: Fasciae of the masticatory space. Anat Rec 129: 383-400 1957.

10) Hai, H.K.: Repair of palatal defects with unlined buccal fat pad grafts. Oral Surg 65: 523-525 1988.

11) Ando, M. and Ando, Y.: Clinical use of lyophilized porcine dermal skin for wound cover. Nagoya Med J 28: 1-13 1983. 